Gut, 1974, 15, 125-129

\title{
Defective biliary excretion of copper in Wilson's disease
}

\author{
D. J. FROMMER 1 \\ From the Department of Medicine, Royal Free Hospital, London
}

SUMMARY The biliary excretion of copper was measured in eight patients with Wilson's disease (three untreated, with hepatic dysfunction) and 10 control subjects (three with hepatic dysfunction). The duodenum was perfused with an amino-acid solution containing a non-absorbed marker, ${ }^{51} \mathrm{CrCl}_{3}$, and juice was aspirated from the duodeno-jejunal junction. The mean concentration of copper in the duodenal aspirate in Wilson's disease was significantly lower than in the control group. The mean biliary copper excretion rate in Wilson's disease of $8.6 \pm 0.8 \mu \mathrm{g} / 20 \mathrm{~min}$ (SEM) was also significantly below that of the control group $(16.4 \pm 0.8 \mu \mathrm{g} / 20 \mathrm{~min})$. The presence of liver dysfunction made no significant difference to the excretion rates in either group of patients. These results suggest that the copper accumulation in Wilson's disease is due to the inability of the liver to excrete copper into bile in adequate amounts.

In man, copper is absorbed by the stomach and upper small intestine (Beckner, Strickland, Leu, and O'Reilly, 1969), concentrated in the liver, and incorporated into caerulosplasmin or excreted into bile (Sass-Kortsak, 1965). It is now generally accepted that in Wilson's disease there is an increased content of copper in the body, the toxic action of which is responsible for damage to the brain, liver, and other organs (Scheinberg and Sternlieb, 1965). The cause of the accumulation is uncertain but it may be the result of either excessive absorption of dietary copper or inadequate excretion. However, if it is due to diminished excretion, this must occur in the gastrointestinal tract, since urinary copper excretion is very low normally and is often raised in Wilson's disease.

Copper balance studies in patients with Wilson's disease (Zimdahl, Hyman, and Cook, 1953; Cartwright, Hodges, Gubler, Mahoney, Daum, Wintrobe, and Bean, 1954; Bickel, Neale, and Hall, 1957; Playoust and Dale, 1961; Sunderman, White, Sunderman, and Lucyszyn, 1963; Goldstein, Randall, Gross, and McGuckin, 1965; Canelas, de Jorge, and Tognola, 1967; Strickland, Blackwell, and Watten, 1971) have shown that faecal copper excretion is below dietary copper intake by up to

\footnotetext{
${ }^{1}$ Requests for reprints to D.J.F., Gastroenterology Department, Prince Henry Hospital, Anzac Parade, Little Bay, NSW 2036, Australia

Received for publication 29 October 1973.
}

$3 \mathrm{mg} / \mathrm{day}$, but they cannot distinguish between increased absorption and decreased biliary excretion as the cause. After oral or intravenous administration of ${ }^{64} \mathrm{Cu}$ or ${ }^{67} \mathrm{Cu}$ there is less radioisotope present in the stools of Wilson's disease patients than in control subjects (Bush, Mahoney, Markowitz, Gubler, Cartwright, and Wintrobe, 1955; Tauxe, Goldstein, Gross, and Randall, 1968a; Tauxe, Goldstein, Randall, and Gross, 1968b; O'Reilly, Weber, Oswald, and Shipley, 1971; Strickland, Beckner, Leu, and O'Reilly, 1972), which could be due to a diminished excretion of radiocopper into bile by the liver in Wilson's disease. This explanation is supported by the demonstration, using external probe counting, of an apparent inability of the liver to discharge ${ }^{64} \mathrm{Cu}$ or ${ }^{67} \mathrm{Cu}$ (Tauxe et al, 1968a), and also by the finding of a diminished concentration of radiocopper in the duodenal bile of patients with Wilson's disease (O'Reilly et al, 1971). However, all these results are explicable on the basis of the radioisotope entering a much enlarged pool of copper in the liver (Sass-Kortsak, 1965; Scheinberg and Sternlieb, 1965) and therefore a much smaller proportion being excreted into bile. It is evident that these studies do not give unequivocal evidence that the absolute quantity of copper excreted into bile by the liver in Wilson's disease is diminished.

Studies on the concentration of copper in bile in normal subjects (Van Ravesteyn, 1944) and in patients with Wilson's disease (Denny-Brown and 
Porter, 1951; Bickel et al, 1957; Cartwright and Wintrobe, 1964) have also yielded inconclusive results, as the values overlap over a wide range. Furthermore, there are no reports of measurements of biliary excretion rates of copper in either normal man or Wilson's disease patients. However, duodenal perfusion studies with non-absorbed marker substances have yielded acceptable estimates of the secretion rates of constituents of bile and pancreatic juice which are independent of the secretion or absorption of water and the completeness of the recovery of duodenal contents (Go, Hofmann, and Summerskill, 1970; Ertan, Brooks, Ostrow, Arvan, Williams, and Cerda, 1971). This technique was used to study biliary copper excretion rates in Wilson's disease patients and control patients.

\section{Patients}

Eight patients with Wilson's disease (11-32 years) were studied; all had low serum copper and caeruloplasmin concentrations, increased urinary copper excretion rates, and raised hepatic copper concentrations. Five of the patients had been treated for two to 21 years and had good liver function. The others, who were newly diagnosed, had hepatitis, and were untreated at the time of the study. Of the 10 control patients (16-67 years), seven had various non-hepatic diseases and good liver function. The diagnoses in the remaining three were cirrhosis of unknown origin (two cases) and recovering hepatitis (probably viral), and all had abnormal liver function tests.

\section{Materials and Methods}

Biliary copper excretion rates were measured by the technique of Go et al (1970), modified by the omission of gastric perfusion. All patients on penicillamine therapy stopped taking the drug at least 48 hours before the study. After an overnight fast, a multilumen tube was passed into the duodenum under radiographic control. Holes in the tube at the level of the second part of the duodenum enabled solutions to be perfused into the duodenum, while the aspiration holes were located at the duodeno- jejunal junction. A solution of $154 \mathrm{mM} \mathrm{NaCl}$ was infused for an initial equilibration period of 20 minutes, followed by a solution containing essential amino acids (Aminosol, Vitrum) very similar in concentration to that used by Go et al (1970). This was infused for between two and three hours, and the infusion rate was $5 \mathrm{ml} / \mathrm{min}$. The duodenum was aspirated continually, the collections being divided into 20-minute periods. Both the $\mathrm{NaCl}$ and amino acid solutions had no detectable copper and contained similar concentrations of the non-absorbed marker, ${ }^{51} \mathrm{CrCl}_{3}(0 \cdot 5-2 \cdot 0 \mu \mathrm{Ci} / 100 \mathrm{ml})$.

The concentrations of ${ }^{51} \mathrm{CrCl}_{3}$ in the aspirates and the perfusion solutions were measured in a well-type counter. Copper concentrations were estimated by acid digestion of samples, followed by extraction with zinc dibenzyldithiocarbamate. The excretion rates of copper into the duodenum were calculated from previously described equations (Go et al, 1970).

The ability of intraduodenal amino acids to stimulate bile flow to a similar degree in the two groups of patients was tested by measuring bile acid concentrations in the duodenal aspirates by a modification of a method for serum bile acids (Murphy, Billing, and Baron, 1970) and then calculating excretion rates.

\section{Results}

The fraction of infused marker recovered in the duodenal aspirate varied from $4.6 \pm 1.6 \%$ to 85.6 $\pm 13.4 \%$ (SEM) in different subjects, and the mean value in Wilson's disease patients, $21.0 \pm 3.7 \%$, did not differ significantly ( $P>0.05$, Student's $t$ test) from that of the control patients, $15.4 \pm 1.3 \%$. However, the mean concentration of copper in the duodenal aspirate during perfusion with amino-acid solution in patients with Wilson's disease was less than half that in the control group (table I), the difference being highly significant $(P<0.001)$. Similarly, the mean biliary copper excretion rate over the whole period of perfusion was very significantly reduced $(P<0.001)$ in Wilson's disease patients compared with that of the control patients. For five

\begin{tabular}{lllc}
\hline & $\begin{array}{l}\text { Marker Recovery } \\
(\%)\end{array}$ & $\begin{array}{l}\text { Cu Concentrations in Aspirate } \\
(\mu \mathrm{g} / 100 \mathrm{ml})\end{array}$ & $\begin{array}{l}\text { Biliary Cu Excretion Rates } \\
(\mu \mathrm{g} / 20 \mathrm{~min})\end{array}$ \\
\hline Wilson's disease & $21.0 \pm 3.7$ & $7.6 \pm 0.6$ & $8.6 \pm 0.8$ \\
Control subjects & $(59)^{2}$ & $(50)$ & $(47)$ \\
& $15.4 \pm 1.3$ & $16.8 \pm 1.4$ & $16.4 \pm 0.8$ \\
\hline
\end{tabular}

Table I Data on duodenal aspirates ${ }^{1}$

1 Values $=$ mean \pm standard error

$\%$ ( $)=$ number of samples 


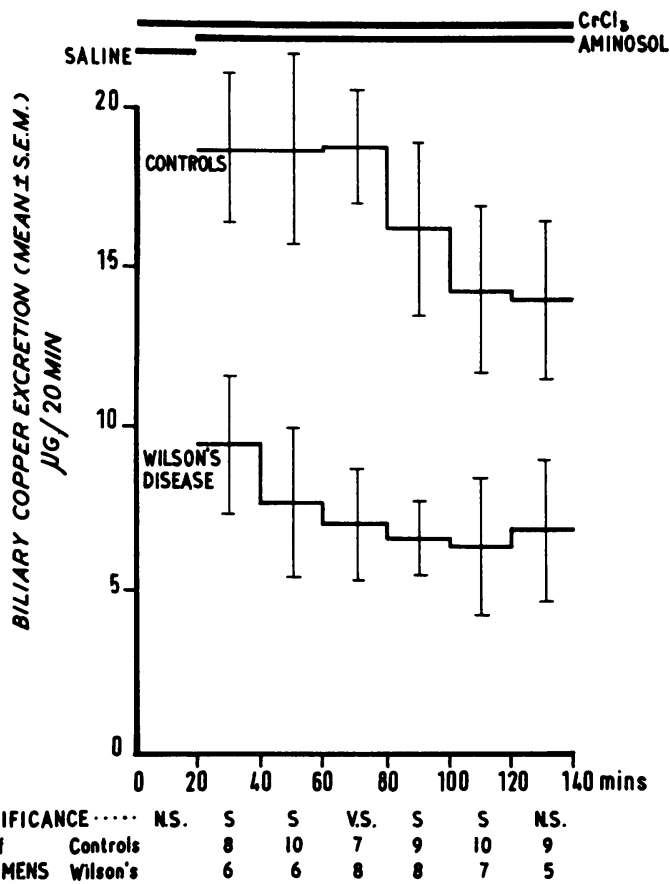

Fig Biliary copper excretion in Wilson's disease patients and controls.

of the six periods of amino acid perfusion (fig) the difference between the two groups was statistically significant. The distribution of values in both groups was normal.

The general pattern of bile acid excretion resembled that for copper in individual patients. The mean rate in Wilson's disease $(318.6 \pm 62.4 \mathrm{mmol} / 20 \mathrm{~min}) \mathrm{did}$ not differ significantly from that of the control patients $(421 \cdot 3 \pm 42 \cdot 4 \mathrm{mmol} / 20 \mathrm{~min})$.

\section{Discussion}

It is likely that the marker perfusion studies have given a valid estimate of biliary copper excretion in the two groups of patients. Although the assump- tion that the marker mixes completely with the duodenal contents is probably only approximately true, the results of other studies (Go et al, 1970; Ertan et al, 1971) show that the use of sufficient collection periods and subjects enables reproducible results to be obtained. The higher level of biliary copper excretion during the first hour of duodenal amino-acid perfusion is attributable to continued gallbladder contraction.

The differences in the copper excretion rates found in the two groups could be due not only to differences in metabolism but also to inadequate stimulation of the liver to produce bile by the amino-acid solution in cases of Wilson's disease, and/or differences in the degree of impairment of liver function. However, the similarity of bile acid excretion rates in the two groups of patients suggests that bile flow was not significantly depressed in the Wilson's disease patients. In addition, in neither group was impaired liver function associated with a significantly diminished biliary copper excretion rate (table II). Both in patients with liver dysfunction and in those without, the copper excretion rates were significantly lower in those with Wilson's disease.

It is very unlikely that the differences found between the two groups of subjects in the rates of copper excreted into the duodenum are due, in fact, to differences in the rates of absorption of biliary copper in the perfused segment of duodenum. In man the main site of absorption of copper appears to be in the stomach rather than the duodenum (Weber, O'Reilly, Pollycove, and Shipley, 1969), and the shortness of the segment perfused (approximately $11.5 \mathrm{~cm}$ ) would have resulted in a rapid transit of duodenal contents. Studies in vitro on the bile of patients with and without Wilson's disease (Frommer, 1971) have indicated that the strength and manner of binding of copper in the two groups of subjects are the same. This contradicts the suggestion that there is increased absorption of biliary copper because it is in a non-bound diffusible form in Wilson's disease (Mistilis and Farrer, 1968).

Assuming a constant rate of excretion of copper into bile by the liver, the control subjects would excrete approximately $1210 \mu \mathrm{g} /$ day and the patients

\begin{tabular}{llll}
\hline Hepatic Function & Wilson's Disease & $P$ Value & Control Subjects \\
\hline Good & $7.5 \pm 1.2$ & $<0.001$ & $16.9 \pm 1.0$ \\
P value & $(29)^{2}$ & & $(51)$ \\
Poor & $>0.05$ & $<0.20$ \\
& $10.5 \pm 1.0$ & $<0.05$ & $14.9 \pm 1.8$ \\
\hline
\end{tabular}

Table II Relationship of biliary copper excretion rates to hepatic function ${ }^{1}$

${ }^{1}$ Values $=$ mean \pm standard error $(\mu \mathrm{g} / 20 \mathrm{~min})$

${ }^{*}()=$ number of samples 
with Wilson's disease $590 \mu \mathrm{g} /$ day. The former value is within the range of 500 to $1300 \mu \mathrm{g} /$ day for normal subjects calculated by Cartwright and Wintrobe (1964). Normal adults must be in copper balance, since the copper content of the body is maintained within a fairly narrow range irrespective of age (Sass-Kortsak, 1965), and the majority of copper balance studies have confirmed this. Therefore, since normally urinary copper excretion is negligible gastrointestinal (mainly biliary) copper excretion must be equal to gastrointestinal copper absorption. If Wilson's disease patients absorb the same amount of copper as normal subjects (viz, $1210 \mu \mathrm{g} /$ day), a biliary copper excretion of $590 \mu \mathrm{g} /$ day would result in a diet-stool difference of $620 \mu \mathrm{g} / \mathrm{day}$. This is close to the figure of $676 \mu \mathrm{g} /$ day for the mean diet-stool difference in Wilson's disease which I have calculated from the data in the literature (Cartwright $e t$ al, 1954; Bickel et al, 1957; Playoust and Dale, 1961; Sunderman et al, 1963; Goldstein et al, 1965; Canelas et al, 1967; Strickland et al, 1971). Diminished biliary copper excretion alone can therefore satisfactorily account for the positive copper balance of Wilson's disease. It should be noted that the difference of approximately $600 \mu \mathrm{g} /$ day between the biliary copper excretion rates of normal subjects and Wilson's disease patients is very much higher than the $50 \mu \mathrm{g} /$ day positive balance postulated as being sufficient to account for the copper retention in Wilson's disease (Scheinberg and Sternlieb, 1965). However, the increased copper excretion in urine in the later stages of the disease will substantially reduce the net positive copper balance.

The finding of diminished biliary copper excretion in Wilson's disease enables a more satisfactory explanation to be given for the accumulation of copper than that of Uzman, Iber, Chalmers, and Knowlton (1956), or of postulating that there is increased copper absorption due either to diminished serum caeruloplasmin levels (Scheinberg and Sternlieb, 1960) or to abnormalities of bile acid metabolism (Lewis, 1973). Since the rate of uptake of copper by the liver in the early stages of the disease is close to normal (Tauxe et al, 1968a), the inability of the hepatocyte to secrete copper into bile or caeruloplasmin into blood could be explained by a block in the intrahepatic handling of copper. Such a block may be due to a deficiency or abnormality in an enzyme involved in the transport of copper from the site of uptake by the hepatocyte or from storage within lysosomes (Sternlieb, Van den Hamer, Morell, Alpert, Gregoriades, and Scheinberg, 1973). As serum concentrations of apocaeruloplasmin have been reported to be near normal in patients with Wilson's disease (Carrico, Deutsch, Beinert, and Orme-Johnson, 1969; Matsuda and Holtzman,
1973), the defective caeruloplasmin production is probably related to the diminished binding of copper to its apoprotein. Further elucidation of the basic defect of Wilson's disease must await a more detailed study of copper metabolism within the liver cell.

This work was supported by the Will Edmonds Research Fund, administered by the Royal College of Physicians, London.

\section{References}

Beckner, W. M., Strickland, G. T., Leu, M. L., and O'Reilly, S. (1969), External gamma scintillation counting of "${ }^{~} \mathrm{Cu}$ over the liver and other sites in patients with Wilson's disease, family members and controls. J. nucl. Med., 10, 320.

Bickel, H., Neale, F. C., and Hall, G. (1957). A clinical and biochemical study of hepatolenticular degeneration (Wilson's disease). Quart. J. Med., 26, 527-558.

Bush, J. A., Mahoney, J. P., Markowitz, H., Gubler, C. J., Cartwright, G. E., and Wintrobe, M. M. (1955). Studies on copper metabolism. XVI. Radioactive copper studies in normal subjects and in patients with hepatolenticular degeneration. J. clin. Invest., 34, 1766-1778.

Canelas, H. M., de Jorge, F. B., and Tognola, W. A. (1967). Metabolic balances of copper in patients with hepatolenticular degeneration submitted to vegetarian and mixed diets. $J$. Neurol. Neurosurg. Psychiat., 30, 371-373.

Carrico, R. J., Deutsch, H. F., Beinert, H., and Orme-Johnson, W. H. (1969). Some properties of an apoceruloplasmin-like protein in human serum. J. biol. Chem., 244, 4141-4146.

Cartwright, G. E., Hodges, R. E., Gubler, C. J., Mahoney, J. P., Daum, K., Wintrobe, M. M., and Bean, W. B. (1954). Studies on copper metabolism. XIII. Hepatolenticular degeneration. J. clin. Invest., 33, 1487-1501.

Cartwright, G. E., and Wintrobe, M. M. (1964). Copper metabolism in normal subjects. Amer. J. clin. Nutr., 14, 224-232.

Denny-Brown, D., and Porter, H. (1951). The effect of BAL (2,3dimercaptopropanol) on hepatolenticular degeneration (Wilson's disease). New Engl. J. Med., 245, 917-925.

Ertan, A., Brooks, F. P., Ostrow, J. D., Arvan, D. A., Williams, C. N., and Cerda, J. J. (1971). Effect of jejunal amino acid perfusion and exogenous cholecystokinin on the exocrine pancreatic and biliary secretions in man. Gastroenterology, 61, 686-692.

Frommer, D. J. (1971). The binding of copper by bile and serum. Clin. Sci., 41, 485-493.

Go, V. L. W., Hofmann, A. F., and Summerskill, W. H. J. (1970). Simultaneous measurements of total pancreatic, biliary, and gastric outputs in man using a perfusion technique. Gastroenterology, 58, 321-328.

Goldstein, N. P., Randall, R. V., Gross, J. B., and McGuckin, W. F. (1965). Copper balance studies in Wilson's disease. Arch. Neurol., 12, 456-462.

Lewis, K. O. (1973). The nature of the copper complexes in bile and their relationship to the absorption and excretion of copper in normal subjects and in Wilson's disease. Gut, 14, 221-232.

Matsuda, I., and Holtzman, N. A. (1973). Detection of apoceruloplasmin by radioimmunoassay. In Proceedings of the 3rd International Symposium on Wilson's Disease, Paris.

Mistilis, S. P., and Farrer, P. A. (1968). The absorption of biliary and non-biliary radiocopper in the rat. Scand. J. Gastroent., 3, 586-592.

Murphy, G. M., Billing, B. H., and Baron, D. N. (1970). A fluorimetric and enzymatic method for the estimation of serum total bile acids. J. clin. Path., 23, 594-598.

Playoust, M. R., and Dale, N. E. (1961). Metabolic balance studies in a patient with Wilson's disease and hypercalcuria. Metabolism, 10, 304-314.

O'Reilly, S., Weber, P. M., Oswald, M., and Shipley, L. (1971). Abnormalities of the physiology of copper in Wilson's disease. III. The excretion of copper. Arch. Neurol., 25, 28-32.

Sass-Kortsak, A. (1965). Copper metabolism. Advanc. clin. Chem., 8, 1-67. 
Scheinberg, I. H., and Sternlieb, I. (1960). Copper metabolism. Pharmacol. Rev., 12, 355-381.

Scheinberg, I. H., and Sternlieb, I. (1965). Wilson's disease. Ann. Rev. Med., 16, 119-134.

Sternlieb, I., Van den Hamer, C. J. A., Morell, A. G., Alpert, S., Gregoriades G., and Scheinberg, I. H. (1973). Lysosomal defect of hepatic copper excretion in Wilson's disease (hepatolenticular degeneration). Gastroenterology, 64, 99-105.

Strickland, G. T., Beckner, W. M., Leu, M. L., and O'Reilly, S. (1972). Turnover studies of copper in homozygotes and heterozygotes for Wilson's disease and controls: isotope tracer studies with ${ }^{67} \mathrm{Cu}$. Clin. Sci., 43, 605-615.

Strickland, G. T., Blackwell, R. Q., and Watten, R. H. (1971). Metabolic studies in Wilson's disease: evaluation of efficacy of chelation therapy in respect to copper balance. Amer. J. Med., 51, 31-40.

Sunderman, F. W., Jr., White, J. C., Sunderman, F, W., and Lucyszyn, G. W. (1963). Metabolic balance studies in hepatolenticular degeneration treated with diethyldithiocarbamate. Amer. J. Med., 34, 875-888.

Tauxe, W. N., Goldstein, N. P., Gross, J. B., and Randall, R. V. (1968a). Turnover studies of intravenously administered radiocopper in patients with Wilson's disease. Effect of D- penicillamine therapy. In Wilson's Disease, (Birth Defects Original Articles Series, Vol. IV, no. 2), edited by D. Bergsma, pp. 45-48. The National Foundation, March of Dimes, New York.

Tauxe, W. N., Goldstein, N. P., Randall, R. V., and Gross, J. B. (1968b). Copper metabolism in carriers of Wilson's disease. An analysis of kinetics of intravenously injected radiocopper as a means of detecting the carrier state. In Wilson's Disease, (Birth Defects Orginal Articles Series, Vol. IV, no. 2), edited by D. Bergsma, pp. 60-63. The National Foundation, March of Dimes, New York.

Uzman, L. L., Iber, F. L., Chalmers, T. C., and Knowlton, M. (1956). The mechanism of copper deposition in the liver in hepatolenticular degeneration (Wilson's disease). Amer. J. med. Sci., 231, 511-518.

Van Ravesteyn, A. H. (1944). Metabolism of copper in man. Acta med. scand., 118, 163-196.

Weber, P. M., O'Reilly, S., Pollycove, M., and Shipley, L. (1969). Gastrointestinal absorption of copper: studies with "Cu, ${ }^{\circ} \mathrm{Zr}$, a whole-body counter and the scintillation camera. $J$. nucl. Med., 10, 591-596.

Zimdahl, W. T., Hyman, I., and Cook, E. D. (1953). Metabolism of copper in hepatolenticular degeneration. Neurology (Minneap.), 3, 569-576.

\section{The January 1974 Issue}

\section{THE JANUARY 1974 ISSUE CONTAINS THE FOLLOWING PAPERS}

Amino acid and peptide absorption in patients with coeliac disease and dermatitis herpetiformis D. B. A. SILK, PARVeen J. Kumar, D. PerRetT, M. L. Clark, AND A. M. DAWSON

Quantitation of the histological changes found in small intestinal biopsy specimens from children with suspected coeliac disease R. A. RISDON AND JEAN W. KEELING

Leucocyte migration studies in Crohn's disease using Crohn's colon homogenate and mitochondrial and microsomal fractions ELIZABETH R. RICHENS, $M$. J. WILLIAMS, K. R. GOUGH, AND R. J. ANCILL

Mixed-lymphocyte reaction as a measure of immunological competence of lymphocytes from patients with Crohn's disease elizabeth R. RICHENS, M. J. WILLIAMS, K. R. GOUGH, AND R. J. ANCILL

${ }^{15} \mathrm{~N}$ studies of endogenous faecal nitrogen in infants WALTER W. C. READ, DONALD S. MCLAREN, AND MARIE TCHALIAN

Carcinoid myopathy and treatment with cyproheptadine (Periactin) ELLIOT M. BERRY, CAROLINE MAUNDER, AND MARIE WILSON
The action of secretin and pancreozymin on smallintestinal alkaline phosphatase T. W. WARNES, P. HINE, AND G. KAY

The treatment of retained stones in the common bile duct with sodium cholate infusion CHARLES LANSFORD, SUNDER MEHTA, AND FRED KERN

Studies in alcoholic liver disease in Britain. 1 Clinical and pathological patterns related to natural history P. W. BRUNT, M. C. KEW, P. J. SCHEUER, AND SHEILA SHERLOCK

\section{Progress report}

The pathophysiology of duodenal ulceration K. G. WORMSLEY

Notes and activities

\section{Historical paper}

On the nature of the acid and saline matters usually existing in the stomachs of animals WILliaM PROUT 